\title{
Green Purchase Behavior: The Role of Religiosity, Environmental Attitude, and Environmental Knowledge
}

\author{
Julina ${ }^{1 *}$, Dwi Kartini ${ }^{2}$, Popy Rufaidah ${ }^{3}$ and Martha Fani Cahyandito ${ }^{4}$ \\ ${ }^{1}$ UIN Suska Riau, Jl. H.R. Soebrantas, 28293, Pekanbaru, Indonesia. \\ ${ }^{2,3,4}$ Universitas Padjadjaran, J1. Dipati Ukur, 40132, Bandung, Jawa Barat, Indonesia.
}

\begin{abstract}
Objective - This study attempts to determine the effect of religiosity, environmental attitudes, and environmental knowledge towards green purchase behavior.

Methodology/Technique - Data were collected by distributing questionnaire to 14 shopping centers in Pekanbaru City during April - September 2016. Pekanbaru city is one of the provincial capital in Indonesia which experienced many environmental problems. A total of 421 eligible respondents participated in this study. Data were analyzed using structural equation modeling.

Findings - The results found that the effect of religiosity, environmental knowledge, and attitude toward green purchase behavior are significant. These three variables explain the green purchase behavior at $67.6 \%$. Besides it also found that religiosity and environmental knowledge have the positive and meaningful impact on environmental attitudes. Therefore, it can be concluded that these two variables affect the green purchase behavior through environmental attitudes.

Novelty - The model built in this study tried to integrate the spiritual aspect that has not been touched by previous researchers. The results of this study open up opportunities for further research to further improve both aspects of modeling in combination with other variables as well as the use of statistical analysis
\end{abstract}

Type of Paper: Empirical

Keywords: Religiosity; Environmental Attitude; Environmental Knowledge; Green Purchase Behavior. JEL Classification: I21, Q56, Q57.

\section{Introduction}

Studying consumer behavior is a fascinating and never-ending topic along with the dynamic development of consumption patterns. Even the issue of environmental damage is also strongly associated with consumer behavior. The principles of seeking profit or benefit as much as possible sometimes lead to uncontrolled exploitation of nature. Imbalances in life, economics, and social situation are one of the problems caused by the current model of economic growth that is maximizing production and consumption. Nowadays, the companies adopting the concept of environmental attitude is not just an adjustment to the issues of particular legislation, but also due to an increasing consumer concern about the environment. Based on the phenomenon, it is important to study consumer behavior to prevent environmental damage from getting worse. Grunert

\footnotetext{
* Paper Info: Received: January 10, 2017

Accepted: July 21, 2017

* Corresponding author:

E-mail: julina@uin-suska.ac.id

Affiliation: Faculty of Economic and Social Sciences, UIN Suska Riau, Indonesia.
} 
(1993) reported that consumer household purchases were responsible for $40 \%$ of the environmental damage. Indonesia, as a country with a huge population, could potentially contribute to the destruction of nature through the behavior of the people. The magnitude of the potential damage caused by consumption patterns that are not environmentally friendly, increasing movements to sensitize the public about keeping the balance of nature. This paper focuses on green purchase behavior as an effort to save the environment. Consumer's environmental attitude is one of major determinant of consumer green purchase behavior. Public awareness on issues of environmental damage is influenced by their knowledge of environmental problems and how to overcome them. Besides attitude and knowledge, religious values of residents in Indonesia was allegedly also influenced their green purchase behavior. Therefore, this present study attempts to explore the influence of religiosity, environmental knowledge, and environmental attitude, towards green purchase behavior. The benefits of this research are to make the right policy relating to drivers of environmentally friendly behavior. The environmentally friendly response will help solve the environmental problem and give the public a better environment.

\section{Literature Review}

\subsection{Consumers' Religiosity}

One of the valuable constructs in understanding consumer behavior is a religion (Fam et al., 2002). Worthington et al., (2003) defined religious commitment as the degree to which a person adheres to his or her religious values, beliefs, and practices and uses them in daily living. Next, Patwardhan, et al. (2012) revealed religiosity as the faith that a person has to God and greatly influences the beliefs and conducts of individuals. Based on the definition of religiosity of some experts, it can be interpreted that religiosity is how far a person has beliefs, preferences, emotions, actions; embrace religious values, beliefs, and practices; and use them in everyday life. Many studies have shown that religion affects consumer attitudes and behavior in general. Mokhlis, (2009) found that people of the Islamic faith are more ethnic conscious, place greater emphasis on traditional family values and display greater fashion conservatism. The possible reason is that Islam has not evolved significantly with modernity. The ardent believer of Islam still follows their traditional beliefs and values. Another research tries to explore the influence of religion in consuming food. Both Islam and Hindu have the restriction of several kinds of food. The influence of religious beliefs on individual and social behavior is well documented (Fam et al., 2002).

\subsection{Environmental Knowledge}

Environmental knowledge is the ability to understand and evaluate the impact of the ecosystem on the society, and the amount of knowledge about environmental issues (Said, Yahaya, \& Ahmadun, 2007). Empirical finding for the relationship between environmental knowledge and behavior is still not conclusive. Chan \& Lau (2000) summarize several past studies that found environmental knowledge has little bearing on environmental behavior (e.g. Arbuthnot and Lingg, 1975; Geller, 1981; and Schahn \& Holzer, 1990). On the other hand, Kilkeary (1975) and Dispoto (1997) found a positive association between the two variables. For further verification, the present study will try to find this association and then explain relevant findings later.

\subsection{Environmental Attitude}

An individual's concern for the environment is fundamental to environmental research (Hines et al. 1987). According to Chan and Lau (2000), environmental attitude is the same meaning with environmental concern. The environmental concern expressed an individual's general orientation toward the environment (Kim and Choi, 2005). Schultz, Shriver, Tabanico, and Khazian, (2004) defined environmental attitude as the collection of beliefs, affect, and behavioral intentions a person holds regarding environmentally related activities or issues. Kim and Choi (2005) examined to the influences of the environmental concern, perceived consumer 
effectiveness and collectivism (which is a cultural characteristic) on environmentally sensitive purchase behavior. Based on their research, environmental attitude is statistically significant in predicting green purchase behavior. Previous studies of environmental or ecological concern have examined this environmental concern as an attitude toward the environment. Besides acting as an independent variable for green purchase behavior, the literature suggests environmental concerns and consumer self-efficacy could become potential intervening variables in the relationship between collectivism and green buying behaviors (Kim \& Choi, 2005). This present study tries to find out whether the environmental attitude could become the intervening variable for religiosity and environmental knowledge toward green purchase behavior as well.

\subsection{Green Purchase Behavior}

Environmentally sensitive behavior implies an individual's efforts to limit negative consequences that may harmful to the physical and natural environment. This could be done by separating and recycling waste, decreasing resource and energy usage, buying an environmentally friendly product, etc. The present study focuses on one type of environmentally sensitive behavior that is green purchase behavior which can be observed in those consumers who buy a green product (e.g. biodegradable garbage bags, soaps, packaging). Consumer green purchase behavior has become one of the most popular research topics among academics, especially in the last three decades. Joshi \& Rahman, (2015) review several past studies and conclude that GPB represents a complex form of ethical decision-making behavior and is considered a type of socially responsible behavior. As socially responsible consumers, the green consumers consider the public consequences of their private consumption and try to use their purchasing power to create social change.

The problem in green purchase behavior is even the people show a positive attitude toward the environment, sometimes they do not behave according to their attitude. Several reasons summarized by Majláth, (2010) are the higher price of green products, the moderate supply of green product, the consumer habit of using the conventional product, lower efficiency and quality of the green product, a limited amount of information available, and so on. Albayrak et al. (2011) reviewed some variables and their influence on green purchase behavior. The independent variables are knowledge, attitude, perceived consumer effectiveness, liberalism, pro-social behavior, and norm. There are eight past types of research which examined the influence of knowledge toward green purchase behavior, but two of them found do not have a significant relationship. For attitude variable, there are 16 past types of research and all of them found a positive significant relationship between attitude and green purchase behavior. From 20 past research reviewed, the religiosity has not been the variable to be tested. Therefore, the present study tries to add a religious variable in examining the effect of attitude and knowledge toward green purchase behavior.

\subsection{The Proposed Model and Hypothesis}

The idea of this study is to evaluates systematically the effects of religiosity, environmental knowledge, environmental attitude, and green purchase behavior and to clarify the interrelationship among the constructs. In light of the aforementioned discussion, a model is developed and Figure 1 offers the proposed model with the hypothesized structural linkages among the variables. General predictions suggest that the religiosity exert direct

effects on green purchase behavior and also indirect effects through environmental attitude. Altogether, environmental knowledge also exerts indirect effects on green purchase behavior through environmental 
attitude as well as the direct effects. Specific hypotheses for the causal paths between the variables are put forth as follows:

H1: Religiosity positively relates to green purchase behavior.

H2: Religiosity positively relates to environmental attitude.

H3: Environmental knowledge positively relates to environmental attitude.

H4: Environmental knowledge positively relates to green purchase behavior.

H5: Environmental attitude positively relates to green purchase behavior.

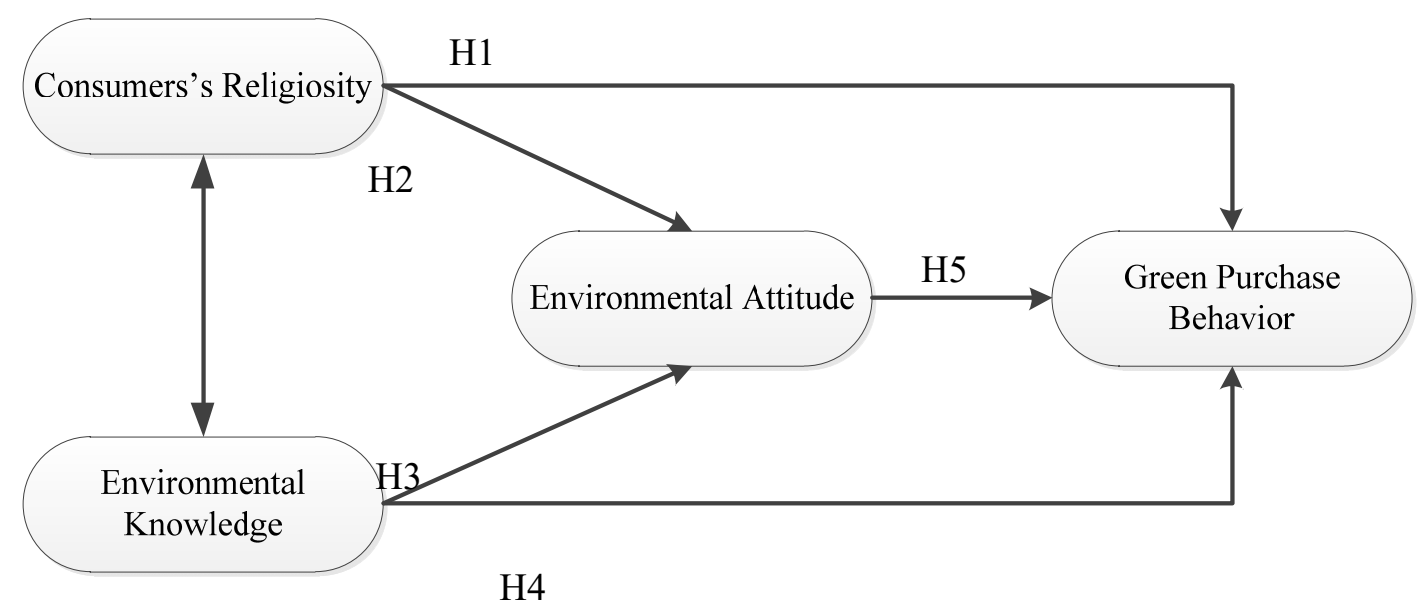

Figure 1. Proposed Model

\section{Research Methodology}

To analysis the relationships in the proposed model, a survey was carried out among consumer in shopping centers in Pekanbaru. Pekanbaru is the capital of Riau province, including the region with an index of environmental quality of life of the lowest in the island of Sumatra. The sample in this study is that consumers who shop in the shopping center because there usually provide many environmentally friendly products, including organic fruits and vegetables. In the first section, some demographics about the participants were aimed to obtain data such as gender, age, religion, and income. In the second section, participants were asked to evaluate their level of religiosity, environmental knowledge, environmental attitude, and green purchase behavior scale. Each latent construct was measured using multiple items, mostly adapted from previous literature. Each item questioned was measured on a 5 point with anchors of (1) "definitely disagree" to (5) "definitely agree". To measure the validity and reliability of questionnaires distributed, this study using confirmatory factor analysis and construct reliability

\section{Results and Discussion}

The gender ratio of the sample was $38.5 \%$ male and $61.5 \%$ female with the average age was 29.4 . The majority of respondents (78.6\%) is Muslim, 3.8\% Catholic, 7.3\% Christian, $1 \%$ Buddhist, Hindu 0.2\%, while $9 \%$ are not willing to mention his religion. To understand interrelationships between the five variables, a proposed structural equation model was examined with Amos Graphic. First, a measurement model that included latent constructs and indicators was first analyzed. Second, the proposed model with hypothesized relationships was tested and refined through a series of tests in an attempt to better explain the data. Several outlier data have been removed so that the samples analyzed totaled 421 respondents. The chi-square for this model is 1007.460 with probability level is 0.000 . The root mean square error of approximation (RMSEA) is lower than the cut-off value $(0.084>0.057)$; goodness-of-fit index $(\mathrm{GFI})$ is 0.845 ; adjusted goodness-of-fit index (AGFI) is 0.821 ; CMIN/DF is 2.354. Table 1 describes the regression weight of proposed model. It can 
be seen that all hypotheses are supported. The highest effect between environmental knowledge and attitudes, while the lowest between knowledge and green purchase behavior. Based on squared multiple correlation tables, the R-square for green purchase is 0.676 means that the effect of religiosity, environmental knowledge, and environmental attitude towards green purchase behavior is $67.6 \%$. Meanwhile, the R-square for environmental attitude is 0.619 means that the effect of religiosity and environmental knowledge towards environmental attitude is $61.9 \%$.

Table 1. Regression Weight

\begin{tabular}{|c|c|c|c|c|c|c|c|}
\hline & & & Estimate & S.E. & C.R. & P & Label \\
\hline Green Purchase & $<---$ & Religiosity & .225 & .045 & 4.968 & $* * *$ & par_32 \\
\hline Attitude & $<---$ & Religiosity & .266 & .047 & 5.671 & $* * *$ & par_29 \\
\hline Attitude & $<---$ & Knowledge & .551 & .058 & 9.501 & $* * *$ & par_33 \\
\hline Green Purchase & $<---$ & Knowledge & .189 & .064 & 2.968 & .003 & par_30 \\
\hline Green Purchase & $<---$ & Attitude & .569 & .083 & 6.812 & $* * *$ & par_31 \\
\hline
\end{tabular}

The relationship between religiosity toward attitude and green purchase behavior is supported at 0.001 levels. Both relationships show a positive and significant. This empirical finding supports the previous research that claimed that there are influences of religious beliefs on individual and social behavior. A research in Brazil found that ecological concern and ecological knowledge variables were considered statistically significant to explain the variations in purchase behavior of ecological cosmetics. This finding is similar to this study as we can see that the effect of knowledge on green purchase is significant (Tamashiro et al., 2013). This study confirms the previous research with statistically significant in the expected direction $(\mathrm{p}<.01)$ for the relationship between knowledge and attitude, meanwhile between environmental knowledge and green purchase behavior is supported at 0.003 . Kim and Choi (2005) also found that environmental attitude has a significant relationship with green purchase behavior. This study supports the finding and found the positive impact between two variables. Research by Mainieri et al. (1997) found that consumers with a stronger concern for the environment are more likely to purchase products as a result of their environmental claims than those who are less concerned about the environmental issues.

The next section will analyze the indirect effect between consumers' religiosity and environmental knowledge of the green purchase behavior through environmental attitudes. As shown in Table 2, environmental attitude is partial mediation as indicated by the VAF score, and it significantly mediates the relation between consumers' religiosity and environmental knowledge toward green purchase behavior.

Table 2. Direct and Indirect Effects

\begin{tabular}{|l|c|c|c|c|c|c|}
\hline Variable & Direct & Indirect & Total & VaF & t & P \\
\hline Religiosity & 0.243 & 0.240 & 0.483 & 0.50 & 6.043 & 0.000 \\
\hline Environmental Knowledge & 0.137 & 0.251 & 0.388 & 0.65 & 5.877 & 0.000 \\
\hline Environmental Attitude & 0.531 & & 0.531 & & & \\
\hline
\end{tabular}

$\mathrm{R}^{2}=0.655$

\section{Conclusion}

Research on green purchase behavior is frequently studied considering much natural damage occurred. Previous researchers have a lot of searching various factors influencing green purchase behavior in order to contribute to better environment changes. In Indonesia with the tendency of the religious population, research on the effect of religiosity on the green purchase behavior is necessary. The model built in this study tried to integrate the spiritual aspect that has not been touched by previous researchers. The results of this study open 
up opportunities for further research to further improve both aspects of modeling in combination with other variables as well as the use of statistical analysis. Based on the findings of this study, the increase in religiosity and knowledge of the environment is necessary in order to improve the environmentally friendly attitude and buying behavior environmentally friendly. Besides the government, religious leaders as a role model of society in implementing religious teaching can focus the study material related to protecting the environment. Meanwhile, to increase knowledge of the environment, it is expected the role of schools as formal educational institutions include material about the environment in an integrated curriculum to be fully applied by students since the early.

\section{References}

Albayrak, T., Caber, M., Moutinho, L., \& Herstein, R. (2011). The influence of skepticism on green purchase behavior. International Journal of Business and Social Science, 2(13). 189-198.

Arbuthnot, J., \& Lingg, S. (1975). A comparison of French and American environmental behaviors, knowledge, and attitudes. International Journal of Psychology, 10(4), 275-281.

Chan, R. Y., \& Lau, L. B. (2000). Antecedents of green purchases: a survey in China. Journal of consumer marketing, 17(4), 338-357.

da Silva Tamashiro, H. R., da Silveira, J. A. G., Merlo, E. M., \& Ghisi, M. (2013). The relationship between ecological knowledge, ecological concern, ecological affection, subjective norms and the green purchase behavior in Brazil. African Journal of Business Management, 7(34), 3297-3314.

Dispoto, R. G. (1977). Interrelationships among measures of environmental activity, emotionality, and knowledge. Educational and psychological measurement, 37(2), 451-459.

Geller, E. S. (1981). Evaluating energy conservation programs: Is verbal report enough?. Journal of Consumer research, 8(3), 331-335.

Grunert, S. C. (1993). Everybody seems concerned about the environment: but is this concern reflected in (Danish) consumers' food choice?. ACR European Advances.

Hines, J. M., Hungerford, H. R., \& Tomera, A. N. (1987). Analysis and synthesis of research on responsible environmental behavior: A meta-analysis. The Journal of environmental education, 18(2), 1-8.

Joshi, Y., \& Rahman, Z. (2015). Factors affecting green purchase behaviour and future research directions. International Strategic Management Review, 3(1), 128-143.

Kilkeary, R. (1975), The energy crisis and decision making in the family, The National Technical Information Service, US Department of Commerce, PB238782

Kim, Y., \& Choi, S. M. (2005). Antecedents of Green Purchase Behavior: An Examination of Collectivism , Environmental Concern, and PCE. Advances in Consumer Research, 32, 592-599

Mainieri, T., Barnett, E. G., Valdero, T. R., Unipan, J. B., \& Oskamp, S. (1997). Green buying: The influence of environmental concern on consumer behavior. The Journal of social psychology, 137(2), 189-204.

Majláth, M. (2010). Can individuals do anything for the environment? The role of perceived consumer effectiveness. Proceedings of FIKUSZ, 10, 157-166.

Mokhlis, S. (2009). Religious differences in some selected aspects of consumer behaviour: a Malaysian study. The Journal of International Management Studies, 4(1), 67-76.

Said, A. M., Yahaya, N., \& Ahmadun, F. L. R. (2007). Environmental comprehension and participation of Malaysian secondary school students. Environmental education research, 13(1), 17-31.

Schahn, J., \& Holzer, E. (1990). Studies of individual environmental concern: The role of knowledge, gender, and background variables. Environment and behavior, 22(6), 767-786.

Schultz, P. W., Shriver, C., Tabanico, J. J., \& Khazian, A. M. (2004). Implicit connections with nature. Journal of environmental psychology, 24(1), 31-42.

Shyan Fam, K., Waller, D. S., \& Zafer Erdogan, B. (2002). The influence of religion on attitudes towards the advertising of controversial products. Www.emeralinsight.com, 38(5), 537-555. http://doi.org/10.1108/03090560410529204.

Worthington Jr, E. L., Wade, N. G., Hight, T. L., Ripley, J. S., McCullough, M. E., Berry, J. W., ... \& O'connor, L. (2003). The Religious Commitment Inventory--10: Development, refinement, and validation of a brief scale for research and counseling. Journal of Counseling Psychology, 50(1), 84-96. 